\title{
MORTGAGE IN THE RUSSIAN FEDERATION IN DECEMBER 2014
}

\author{
G.Zadonsky
}

Despite worsening of the financial and economic situation, within 11 months of 2014 the volume of mortgage housing loans (MHL) (Rb 1530.3bn) exceeded by $22.2 \%$ and $30.2 \%$ in quantitative terms and monetary terms, respectively, the volume of MHL extended within the respective period of 2013. As of December 1, 2014, the share of overdue debt in the outstanding debt on $\mathrm{MHL}$ fell to $0.8 \%$ and increased to $14.5 \%$ as regards loans in rubles and loans in foreign currency, respectively. However, in November 2014 the weighted average rate on MHL in rubles extended within a month amounted to 12.6\% against 11.9\% in November 2013.

According to the data of the Central Bank of Russia, in November 2014 Rb 143.6bn worth of 81,352 mortgage housing loans was extended (Fig. 1), which values were $12.39 \%$ and $12.96 \%$ lower as regards the number of loans and their monetary volume, respectively, as compared to October. As of December 1, 2014, $\mathrm{Rb} 1,530.3 \mathrm{bn}$ worth of $878,591 \mathrm{MHL}$ was extended from the beginning of the year with the debt of $\mathrm{Rb} 3,442.7 \mathrm{bn}$ (Fig. 1). From the beginning of 2014, there was $22.16 \%$ and $30.2 \%$ more loans extended in quantitative terms and monetary terms, respectively, as compared to the same period of 2013. Prevalence of mortgages in housing lending kept growing and as of December 1, 2014 the volume of MHL from the beginning of the year amounted to $96.9 \%$ of the volume of housing loans (HL). In 2014, from the beginning of the year the average value of $\mathrm{MHL}$ in rubles and foreign currency kept growing and as of December 1 amounted to $\mathrm{Rb} 1.73 \mathrm{~m}$ and $\mathrm{Rb} 12.09 \mathrm{~m}$ in rubles and foreign currency, respectively, having exceeded the average value as of December 1, 2013 by $7.2 \%$ and $43.59 \%$ in rubles and foreign currency, respectively. As of December 1, 2014, the volume of the extended HL amounted to $\mathrm{Rb} 1,579.1 \mathrm{bn}$ or 920,742 loans with the debt of Rb 3,5691bn (Fig.1).

As of December 1, 2014, the overdue debt on MHL rose by $5.7 \%$ as compared to November 1, 2014 and amounted to $\mathrm{Rb} 46.29 \mathrm{bn}$. It is to be noted that in November 2014 the share of the overdue debt in the outstanding debt on MHL decreased by 0.01 p.p. as regards loans in rubles and amounted to $0.83 \%$, while that as regards loans in foreign currency increased by 0.33 p.p. to $14.5 \%$.

According to the data of the Central Bank of the Russian Federation, in November 2014 the share of the debt on MHL without overdue payments to the total amount of the debt on MHL increased by 0.35 p.p. and amounted to $95.6 \%$. The share of the debt on the defaulted loans (with payments overdue for over 180 days) in the total amount of the debt on MHL

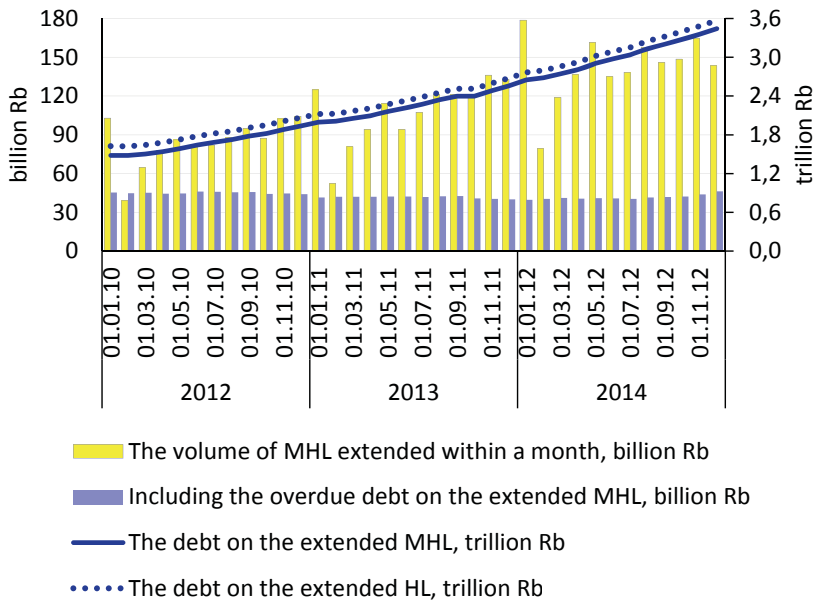

Source: the data of the Central Bank of the Russian Federation. Fig. 1. Housing lending dynamics

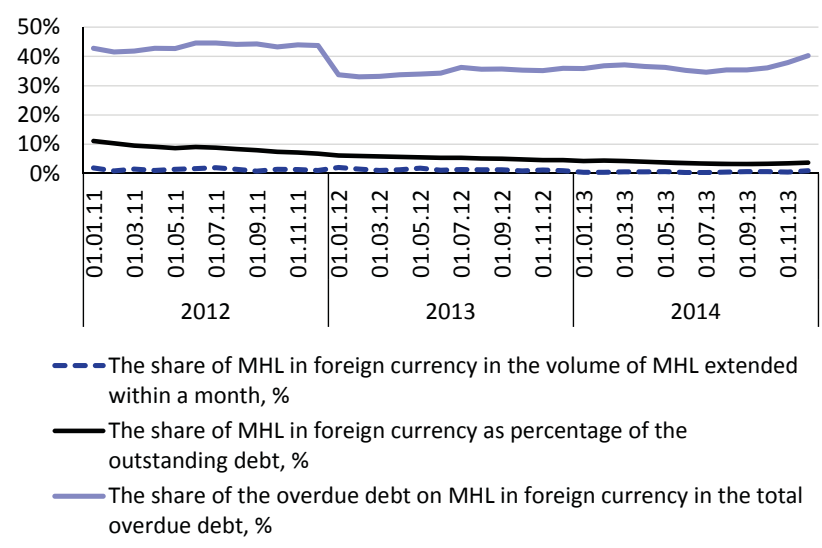

Source: on the basis of the data of the Central Bank of the Russian Federation.

Fig. 2. Mortgage loans in foreign currency in the main indices of the mortgage market

increased by 0.06 p.p. and amounted to $1.74 \%$, which was 0.17 p.p. lower as compared to December 1, 2013.

The share of MHL in foreign currency in the volume of loans extended in November 2014 amounted to $0.96 \%$, which was 0.47 p.p. higher than in October 2014. As of December 1, 2014, the share of such loans 
in the outstanding debt rose by 0.25 p.p. as compared to November 1 and amounted to $3.73 \%$, while the share of the overdue debt on MHL in foreign currency in the total overdue debt amounted to $40.24 \%$ as of December 1, 2014 (Fig. 2).

In November 2014, the weighted average rate on MHL in rubles extended within a month amounted to $12.61 \%$, which was 0.24 p.p. lower than in October 2014. The weighted average rate within a month on loans refinanced by the OAO Agency for Housing Mortgage Lending (AHML) amounted (the latest published value) to $11.1 \%$ in May 2014 which value was within the limits of fluctuations of the rate in the previous months of the year (Fig. 3). The weighted average rate on $\mathrm{HL}$ in rubles extended within a month amounted to $12.6 \%$ in November 2014, having decreased by 0.23 p.p. within a month. As of December 1, 2014, the weighted average rate on $\mathrm{MHL}$ in rubles extended from the beginning of the year amounted to $12.35 \%$, while that on $\mathrm{MHL}$ in foreign currency, to $9.26 \%$. In November 2014, the weighted average period of lending as regards $\mathrm{MHL}$ in rubles extended within a month amounted to 15.12 years (Fig. 3 ), while that as regards $\mathrm{HL}$ in rubles, to 15.05 years. As of December 1, 2014, the weighted average period of lending as regards $\mathrm{MHL}$ in foreign currency extended from the beginning of the year amounted to 11.66 years.

The share of unsecured housing loans (UHL) extended within a month as a difference between $\mathrm{HL}$ and MHL in shares of HL in November 2014 decreased by 1.03 p.p. to $3.1 \%$ and 0.52 p.p. to $2.7 \%$ in quantitative terms and monetary terms, respectively (Fig. 4). The debt on UHL as percentage of the debt on HL was steadily decreasing (Fig. 4) and as of December 1, 2014 amounted to 3.5\%. As of December 1, 2014, the overdue debt on UHL as percentage of the outstanding debt on UHL amounted to $2.6 \%$, which value exceeds 1.93 times over the value of the overdue debt on MHL as percentage of the outstanding debt within the same period (1.34\%). The average value of UHL (Rb 1,521m) is growing, but remains below (86.2\%) the average value of MHL. A lower quality of UHL as compared to $\mathrm{MHL}$ is the main factor behind a decrease in the share of UHL in housing lending.

In January-December 2014, the OAO AHML refinanced $\mathrm{Rb} 50,268 \mathrm{bn}$ worth of $32,392 \mathrm{MHL}$, which values are $0.98 \%$ and $4.7 \%$ lower in quantitative terms and monetary terms, respectively. In the total volume of $\mathrm{MHL}$ extended in the Russian Federation in January-November 2014, the share of loans refinanced by the OAO AHML amounted to $3.7 \%$ and $3.3 \%$ in quantitative terms and monetary terms,

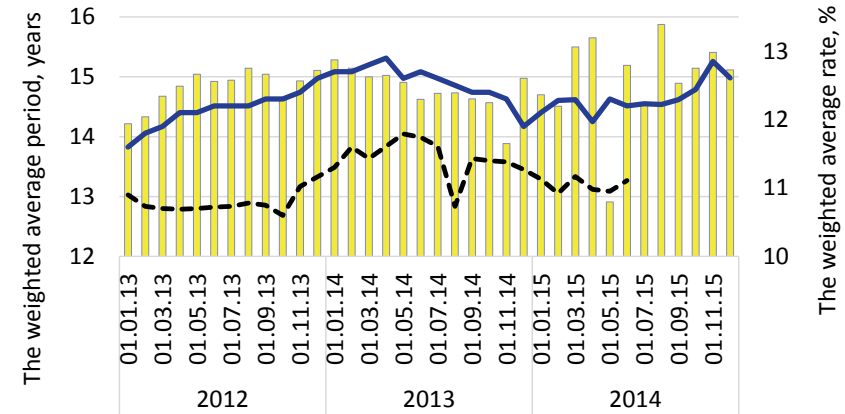

$\square$ The weighted average period of lending as regards MHL extended within a month, years

The weighted average rate on MHL extended within a month, \%

- - The weighted average rate on mortgages refinanced by the OAO AHML within a month, \%.

Source: The Central Bank of the Russian Federation and the OAO AHML.

Fig. 3. The weighted average periods of lending and interest rates on $\mathrm{MHL}$ in rubles extended within a month

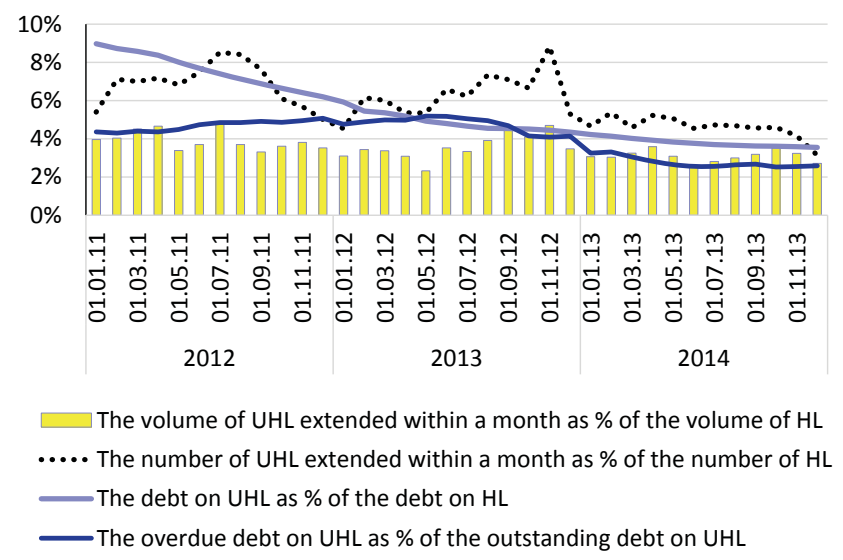

Source: on the basis of the data of the Central Bank of the Russian Federation

Fig. 4. Dynamics of unsecured housing lending (UHL)

respectively, and as compared to the same period of 2013 decreased by 1.99 p.p. and 0.28 p.p. in quantitative terms and monetary terms, respectively. In January-November 2014, within the frameworks of implementation of social mortgage programs the OAO AHML refinanced $\mathrm{Rb} 24.3 \mathrm{bn}$ worth of 13,226 mortgage loans which values are equal to $48.5 \%$ and $57.2 \%$ as regards the number of refinanced loans and their monetary volume, respectively. Within 11 months of 2014, the OAO AHML took part in 11 issues of mortgage-backed securities for the total sum of $\mathrm{Rb} 61.1 \mathrm{bn}$ ( $47.4 \%$ of the total volume of the issued mortgagebacked securities).

The OAO AHML declared that it would raise interest rates on average by 2-4 p.p. on loan refinancing programs and was going to reduce the volume of refinancing to $\mathrm{Rb} 8 \mathrm{bn}$ in $\mathrm{H} 12015$. 